\title{
MONITORING OF THE STATE ECONOMIC SECURITY: METHODOLOGICAL SUPPORT AND PRACTICAL IMPLEMENTATION
}

\author{
Assoc. Prof. PhD. Irina R. Ruiga
}

Prof., DSc. Alyona A. Stupina

Assoc. Prof. PhD. Larissa N. Korpachyova

Assoc. Prof. PhD. Natalya N. Dzhioyeva

Assistant Tatiana A. Burmenko

Siberian Federal University, Russia

\begin{abstract}
The article presents a theoretical analysis of existing approaches to assessing threats to the state economic security. The analysis revealed three main methods for assessing economic security: a simple rationing method based on a threshold value, a complex rationing method based on a threshold value, a rationing method for amount of discrepancy. These methods, despite the presence of specific features, are implemented in a certain sequence. As a result of the synthesis of methodological approaches, the authors have formed an assessment algorithm (conducting a monitoring procedure) of threats to the state economic security.

To study the analytical capabilities of the proposed assessment algorithm, the sequence of its application is considered on the example of the Russian Federation for the period from 2013 to 2017. The information base for the assessment was compiled by the World Bank, the Federal State Statistics Service, the Central Bank of the Russian Federation, Federal Customs Service of Russia. The calculated integral indicators of the state economic security for the relevant periods of time are properly interpreted; were identified factors that have a negative impact on the level of economic security of Russia.

According to the authors, the combination of various methods (the indicative method, the method of normalized values, the integral method) makes it possible to ensure a certain adequacy of the assessment of the state economic security level. As a result, the analysis of the assessment results becomes the basis for the development by the federal authorities of a set of measures and mechanisms for ensuring economic security in the aspect of updating strategic documents.
\end{abstract}

Keywords: economic security of the state; threat assessment techniques; threat monitoring.

\section{INTRODUCTION}

The ongoing changes in the geopolitical situation marked the beginning of new approaches in the field of political, economic and military relations of different countries. Under these conditions, ensuring national security is closely related to the 
solution of economic issues, which, in turn, actualizes the problem of ensuring the state economic security and practical recommendations in this direction.

The practical aspects of the importance of studying the problems of the state economic security are also due to a number of internal and external circumstances. In particular, in recent years there has been an aggravation of economic and sociopolitical problems in countries with developed economies: the state budget deficit, rising unemployment rates, an increase in the "shadow economy" sector, negative effects of production decline, political instability, and increased social tension in the society. As a result, the economic fundamentals of national security are being destroyed. An equally important aspect of this problem is that in the conditions of weakening of some countries, the desire of others to military-technological superiority over them, the use of "economic levers" of pressure to achieve their political interests. Ensuring the economic security of the state is inextricably linked with the issues of maintaining a certain balance of foreign economic relations and their influence on the processes of social and economic transformations, as well as ensuring the defense capability of the state.

In this study, under the economic security the authors mean a state of protection of the national economy from external and internal threats, which provide the economic sovereignty of the country, the unity of its economic area, the conditions for the implementation of strategic national priorities.

One of the important aspects of ensuring the economic security of the state is its assessment, as a result of which external and internal threats are identified. In modern analytical practice, various approaches are used to assess the economic security of the state, but no justification is provided as to which of the proposed approaches provide the most objective characterization of the studied phenomenon.

The purpose of this study is a theoretical analysis of existing approaches to assessing threats to the state economic security, the formation of an assessment algorithm resulting from the synthesis of methodological approaches (conducting a monitoring procedure) and its approbation using the example of the Russian Federation.

\section{Methods}

Under the assessment of the state security level is commonly understood the process of determining the measure of the proximity of its actual state to the state of complete security [1]. Such an assessment involves comparing the target state of economic development with its actual state and can be a measure of meeting its goals (objectives) to ensure it.

As a result of the theoretical analysis [2, 3, 4, 5, 6, 7] three main methods for assessing economic security were identified: a simple rationing method for a threshold value, a complex rationing method for a threshold value, a rationing method for amount of discrepancy.

At the first stage of the assessment, a set of initial parameters (indicators) characterizing the state of economic security of the state and the degree of its protection is determined. Further, indicators are subject to quantification and rationing in order to bring them to a comparable form and comparable units of measurement.

For practical purposes, various methods (models) are used to ration indicators. Part of the models of valuation uses the so-called threshold values of indicators, which separate the dangerous state of the object from the safety one. However, in national practice there is no generally accepted approach to the selection of indicators and the determination of their threshold values. To establish the threshold values, we apply the method of averaged comparison with indicators of other countries in a fixed period of time and expert estimates. 
After the rationing procedure, a number of approaches provide the calculation of the integral indicator value for groups of normalized indicators and (or) the object as a whole. Using the expert method, the interval for changing the values of an integral indicator is divided into subintervals (levels), which are assigned to increasing or decreasing safety levels.

The summarizing (integral) indicator of normalized indicators can be presented in three ways: in the form of a product of indicators, their sum and in the form of a metric [8]. In general, the ranks of generalizing indicators calculated by different methods of the same object do not necessarily have a similar order and may not coincide.

In each of the considered models for calculating a generalizing indicator, the possibility of using weighting factors, which are determined by an expert method is envisaged. It should be noted that modern methods of assessing economic security ignores the fact that in addition to such weights that reflect the relative significance (importance) of a group of indicators or objects, there are still probabilities of the occurrence of existing threats to the state economic security.

Summarizing the advantages and disadvantages of scientific approaches to assessing the state economic security, the most reasonable method from the point of view of practical implementation, according to the authors, seems to be based on the formation of an integral index. The integrated index (or index) is formed with the partial indicators that previously normalized by the amount of discrepancy between actual and their threshold values.

In determining such particular indicators, it is important to take into account two key criteria: 1) indicators should be suitable for conducting a comparative analysis of the state economic security; 2) sources of information on indicators should ensure the accuracy of the data.

In order to form an algorithm for assessing state economic security, it is advisable to group the indicators into four blocks $\left(\mathrm{k}_{\mathrm{i}}\right)$ (Figure 1$)$, and assign a weight value to each of which $\left(\mathrm{w}_{\mathrm{i}}\right)$.

Stage I. Formation of indicators system of state economic security and their threshold values

Stage II. Differentiation of indicators and their subsequent grouping with assignment of weight values

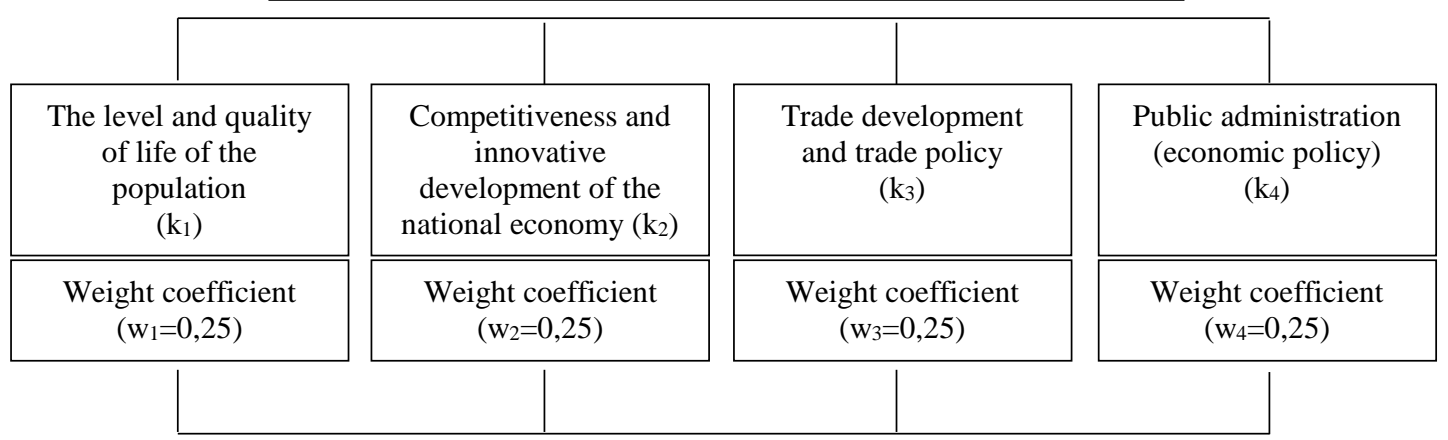

Stage III. Integral assessment of the state economic

$$
\begin{gathered}
\text { security } \\
\mathrm{I}_{\mathrm{ES}}=\sum_{n}^{i} k_{i} \times w_{i}
\end{gathered}
$$

Figure 1 - Algorithm for assessing the state economic security (compiled by the authors) 
In the framework of this study, it was assumed that each group of indicators is of equal value $\left(w_{i}=0,25\right)$. The authors do not exclude that, depending on the purpose of economic security monitoring, the list of indicators groups may be changed.

Then it is necessary to perform a series of analytical actions:

1) to compare the actual and threshold values of the estimated indicators and calculate the normalized values. It is proposed to use a simple normalization, in which it is proposed to apply for each indicator only one threshold value - upper or lower. The calculation of the normalized value with a lower threshold value represents the ratio of the actual value to the threshold one. The calculation of the normalized value with the upper threshold value represents the ratio of the threshold value to the actual one;

2) to calculate the integral indicator of the state economic security as a weighted average;

3) to interpret the result obtained and give a qualitative description of the state economic security, as well as determine the most relevant areas for neutralizing the identified threats to the safe status of the country's economy.

\section{Results}

To examine the analytical possibilities of the proposed algorithm for assessing the state economic security, we consider the sequence of its application using the example of the Russian Federation for the period from 2013 to 2017.

The information base for the assessment was compiled by the data of the World Bank Group (International Bank for Reconstruction and Development, International Development Association, International Monetary Fund etc.) [9], the Federal State Statistics Service [10], the Central Bank of the Russian Federation [11], Federal Customs Service of Russia [12].

The complex of indicators for assessing the state economic security is proposed to be formed on the basis of a list of the main characteristics of the state of economic security stipulated by the Decree of the President of the Russian Federation of May 13, 2017 No. 208 «On the Strategy for Economic Security of the Russian Federation for the period until 2030» [13], which includes 40 indicators. Their composition can be refined according to the results of monitoring, however, a list of indicators is adopted as an initial set of indicators, which is defined in the Strategy. A set of indicators differentiated into 4 groups was selected from the initial data array; weights were assigned to each of the indicators (Table 1).

Table 1 - Indicators assessing the state economic security (compiled by the authors)

\begin{tabular}{|c|c|c|}
\hline Indicator & $\begin{array}{l}\text { Threshold } \\
\text { value* }\end{array}$ & $\begin{array}{l}\text { Weight } \\
\text { value }\end{array}$ \\
\hline \multicolumn{3}{|l|}{ The level and quality of life of the population } \\
\hline $\begin{array}{l}\text { 1.1. Gross domestic product per capita (at purchasing power } \\
\text { parity), USD }\end{array}$ & 20520 & 0,50 \\
\hline 1.2. Unemployment rate, $\%$ & 8 & 0,20 \\
\hline 1.3. Share of the working age population in the total population, $\%$ & 60 & 0,30 \\
\hline \multicolumn{3}{|l|}{ Competitiveness and innovative development of the national economy } \\
\hline 2.1. Index of physical volume of gross domestic product (GDP) & 101 & 0,40 \\
\hline 2.2. Inflation rate, $\%$ & 125 & 0,30 \\
\hline $\begin{array}{l}\text { 2.3. The share of high-tech and knowledge-intensive industries in } \\
\text { the gross domestic product, \% to GDP }\end{array}$ & 25 & 0,30 \\
\hline \multicolumn{3}{|l|}{ Trade development and trade policy } \\
\hline 3.1. Balance of trade, $\%$ of foreign trade turnover & 8 & 0,40 \\
\hline 3.2. The index of exports physical volume, $\%$ & 105 & 0,35 \\
\hline
\end{tabular}


3.3. Retail volume index, \% Public administration (economic policy)

\begin{tabular}{|c|c|c|}
\hline 4.1. Doing Business index & 100 & 0,30 \\
\hline 4.2. National debt, $\%$ of GDP & 60 & 0,35 \\
\hline 4.3. Budget deficit, $\%$ of GDP & 3 & 0,35 \\
\hline
\end{tabular}

* Calculated by the authors according to [7, 9, 10, 11, 12, 14]

After forming a list of indicators for assessing the state economic security, it is necessary to determine the threshold value for each of the parameters. Taking into account certain limitations associated with the absence of officially fixed reference values, let us turn to the results of scientific research of Russian scientists on this subject [7, 15]. In particular, a number of threshold values of the state's economic security is determined on the basis of comparisons with average values of similar indicators for the G7 countries. S.Yu. Glazyev proposed to establish the threshold value for the indicator «GDP per capita» in the amount of 50\% of the average for the G7 countries [16]. At the prices of 2013 GDP per capita for the G7 countries averages 4,103.19 USD [10].

The threshold value for unemployment is advisable to set at $8 \%$, taking into account that the average value for the G7 countries is $8.11 \%$.

The share of the working age population in the total population in the G7 countries is $59.66 \%$ on average. Therefore, for the purposes of this study, the threshold value of this indicator is taken at the level of $60 \%$.

The average inflation rate for the G7 countries in 2013 was $1.27 \%$ per year. However, for Russian conditions, other criteria are more often used, ranging from 20 to 25\% per year. In particular, according to V.K. Senchagov [7], inflation threshold value is determined at the level of $125 \%$. In the context of a permanent financial crisis, which to a greater or lesser extent determines the conditions for the functioning of the Russian economy, the proposed threshold value of the inflation rate seems relevant [7].

In determining the threshold values for the budget deficit and public debt indicators, the standard values used by the Accounts Chamber of the Russian Federation and the Central Bank of the Russian Federation are taken into account. In particular, the threshold of $60 \%$ is set for the indicator of «public debt in\% to GDP» [14].

The admissible values of the budget deficit indicator correspond to the IMF criteria for a balanced state budget, according to which the size of the budget deficit does not exceed $3 \%$ of GDP.

Threshold values in terms of volume indices of GDP, the physical volume of exports and retail sales are set to the average for the period. Threshold value for Doing Business index defined as the maximum possible value of the indicator at the level of 100 [9], to which all rating participants strive including Russia.

The share of high-tech industries in GDP is set at 25\%, which corresponds to the target parameters reflecting the state's economic policy in the real economy [13].

Thus, the formed system of threshold values (Table 1) gives a basis for further calculations.

When comparing the actual values of the estimated indicators of economic security with their threshold values, we calculate the dimensionless values of the indicators (since the system includes indicators with different measurement values). The calculation results are presented in accordance with Table 2. 
Table 2 - The normalized values of indicators for assessing the economic security of the Russian Federation, 2013-2017*

\begin{tabular}{|c|c|c|c|c|c|}
\hline Indicator & 2013 & 2014 & 2015 & 2016 & 2017 \\
\hline \multicolumn{6}{|l|}{ 1. 1. The level and quality of life of the population $\left(k_{1}\right)$} \\
\hline $\begin{array}{l}\text { 1.1. Gross domestic product per capita (at purchasing } \\
\text { power parity), USD }\end{array}$ & 1,279 & 1,257 & 1,206 & 1,210 & 1,244 \\
\hline 1.2. Unemployment rate, $\%$ & 1,455 & 1,538 & 1,429 & 0,976 & 1,455 \\
\hline $\begin{array}{l}\text { 1.3. Share of the working age population in the total } \\
\text { population, } \%\end{array}$ & 1,002 & 0,988 & 0,973 & 0,957 & 0,945 \\
\hline \multicolumn{6}{|c|}{ 2. Competitiveness and innovative development of the national economy $\left(\mathrm{k}_{2}\right)$} \\
\hline $\begin{array}{l}\text { 2.1. Index of physical volume of gross domestic } \\
\text { product (GDP) }\end{array}$ & 1,008 & 0,997 & 0,965 & 0,988 & 1,005 \\
\hline 2.2. Inflation rate, $\%$ & 1,174 & 1,123 & 1,107 & 1,186 & 1,219 \\
\hline $\begin{array}{l}\text { 2.3. The share of high-tech and knowledge-intensive } \\
\text { industries in the gross domestic product, } \% \text { to GDP }\end{array}$ & 0,844 & 0,872 & 0,852 & 0,864 & 0,868 \\
\hline \multicolumn{6}{|l|}{ 3. Trade development and trade policy $\left(\mathrm{k}_{3}\right)$} \\
\hline 3.1. Balance of trade, $\%$ of foreign trade turnover & 3,125 & 3,350 & 3,813 & 2,763 & 2,788 \\
\hline 3.2. The index of exports physical volume, $\%$ & 0,961 & 1,024 & 1,002 & 1,005 & 1,009 \\
\hline 3.3. Retail volume index, $\%$ & 1,008 & 1,004 & 0,978 & 0,993 & 1,016 \\
\hline \multicolumn{6}{|l|}{ 4. Public administration (economic policy) $\left(\mathrm{k}_{4}\right)$} \\
\hline 4.1. Doing Business index & 0,436 & 0,659 & 0,710 & 0,732 & 0,755 \\
\hline 4.2. National debt, $\%$ of GDP & 4,724 & 3,846 & 3,774 & 3,846 & 3,448 \\
\hline 4.3. Budget deficit, $\%$ of GDP & 2,500 & 2,727 & 0,882 & 0,833 & 2,000 \\
\hline
\end{tabular}

* Calculated by the authors according to $[9,10,11,12]$

At the next stage of the calculations, we will determine the values of the integral indicator of the state economic security, using the previously determined weight values of the indicators. The results of the calculations are reflected in accordance with table 3.

Table 3 - Dynamics of the integral indicator of assessing the economic security of the Russian Federation, 2013-2017*

\begin{tabular}{|l|c|c|c|c|c|c|}
\hline \multicolumn{1}{|c|}{ Indicator } & $\begin{array}{c}\text { Weight } \\
\text { value }\end{array}$ & 2013 & 2014 & 2015 & 2016 & 2017 \\
\hline $\begin{array}{l}\text { 1. The level and quality of life of the } \\
\text { population (k } 1 \text { ) }\end{array}$ & 0,25 & 1,231 & 1,233 & 1,181 & 1,087 & 1,196 \\
\hline $\begin{array}{l}\text { 1.1. Gross domestic product per capita (at } \\
\text { purchasing power parity), USD }\end{array}$ & 0,5 & 0,640 & 0,629 & 0,603 & 0,605 & 0,622 \\
\hline 1.2. Unemployment rate, \% & 0,2 & 0,291 & 0,308 & 0,286 & 0,195 & 0,291 \\
\hline $\begin{array}{l}\text { 1.3. Share of the working age population in } \\
\text { the total population, \% }\end{array}$ & 0,3 & 0,301 & 0,296 & 0,292 & 0,287 & 0,284 \\
\hline $\begin{array}{l}\text { 2. Competitiveness and innovative } \\
\text { development of the national economy (k })\end{array}$ & 0,25 & 1,009 & 0,997 & 0,974 & 1,010 & 1,028 \\
\hline $\begin{array}{l}\text { 2.1. Index of physical volume of gross } \\
\text { domestic product (GDP) }\end{array}$ & 0,4 & 0,403 & 0,399 & 0,386 & 0,395 & 0,402 \\
\hline 2.2. Inflation rate, \% & 0,3 & 0,352 & 0,337 & 0,332 & 0,356 & 0,366 \\
\hline $\begin{array}{l}\text { 2.3. The share of high-tech and knowledge- } \\
\text { intensive industries in the gross domestic } \\
\text { product, \% to GDP }\end{array}$ & 0,3 & 0,253 & 0,262 & 0,256 & 0,259 & 0,260 \\
\hline 3. Trade development and trade policy (k $\left.\mathrm{k}_{3}\right)$ & 0,25 & 1,838 & 1,949 & 2,120 & 1,705 & 1,722 \\
\hline 3.1. Balance of trade, \% of foreign trade & 0,4 & 1,250 & 1,340 & 1,525 & 1,105 & 1,115 \\
\hline
\end{tabular}




\begin{tabular}{|l|c|c|c|c|c|c|}
\hline \multicolumn{1}{|c|}{ Indicator } & $\begin{array}{c}\text { Weight } \\
\text { value }\end{array}$ & 2013 & 2014 & 2015 & 2016 & 2017 \\
\hline \hline turnover & & & & & & \\
\hline $\begin{array}{l}\text { 3.2. The index of exports physical volume, } \\
\%\end{array}$ & 0,35 & 0,336 & 0,358 & 0,351 & 0,352 & 0,353 \\
\hline 3.3. Retail volume index, \% & 0,25 & 0,252 & 0,251 & 0,245 & 0,248 & 0,254 \\
\hline $\begin{array}{l}\text { 4. Public administration (economic policy) } \\
\text { (k4) }\end{array}$ & 0,25 & 2,659 & 2,498 & 1,843 & 1,857 & 2,133 \\
\hline 4.1. Doing Business index & 0,35 & 1,654 & 1,346 & 1,321 & 1,346 & 1,207 \\
\hline 4.2. National debt, \% of GDP & 0,35 & 0,875 & 0,955 & 0,309 & 0,292 & 0,700 \\
\hline 4.3. Budget deficit, \% of GDP & & 1,684 & 1,669 & 1,529 & 1,415 & 1,520 \\
\hline
\end{tabular}

* Calculated by the authors

According to the results of calculations, the level of economic security of the Russian Federation in 2013-2017 ranged from 1,415 to 1,684, a negative trend could be observed until 2016, after this year the state of the economy began to gradually improve.

Factors reducing the economic security of Russia in 2013-2016 were: a decrease in the index of physical volume of gross domestic product, an increase in the budget deficit (despite a significant excess of the threshold value), a relatively low share of high-tech and knowledge-intensive industries in the gross domestic product (failure to reach the threshold throughout the reviewed period), an increase in the unemployment rate (2016) and reducing in the proportion of the working population. To identify the entire spectrum of threats to economic security, the dynamics of economic indicators require more detailed study.

\section{Conclusion}

The study of modern approaches to the analysis and evaluation of economic security at the state level indicates that, despite the great scientific interest and practical significance, the problem of substantiating the relevant methodology has not been adequately addressed. Methodical approaches developed at various stages of the development of the national economy are not widely used and continue to be discussed for their consistency.

According to the authors, the proposed algorithm for assessing economic security at the state level is characterized by the presence of an integrated approach - the quantitative assessment procedure is carried out on the basis of a system of criteria and indicators characterizing the level of socio-economic system development. Based on the goals and objectives of the implemented economic policy at the federal level, the set of indicators used for the assessment can be adjusted. In this case, it is advisable to carry out an aggregated assessment based on the differentiation of indicators into integrated groups. By analogy, the distribution of weight values and threshold standards may be adjusted. It is natural that in the conditions of all the increasingly complex economic and political relations, all indicators of economic security cannot remain within the established norms.

During the evaluation procedure, it is possible to set a different planning horizon (short-term, medium-term and long-term), depending on the scale of the objectives of state authorities at the macro level.

The combination of various methods (the indicative method, the method of normalized values, the integral method) allows to ensure a certain adequacy of the assessment of the level of state economic security. Eventually the analysis of the 
assessment results becomes the basis for the development by the federal authorities of a set of measures and mechanisms for ensuring economic security in the aspect of the adjustment strategic documents. The authors admit the possibility of using additional methods. For example, in the aspect of identifying factors that have a negative impact on the level of economic security, it is advisable to use the methods of correlation and regression analysis. One of the most significant limitations that analysts face when conducting economic security assessments at the federal level is the lack of clear criteria for interpreting the results obtained. This complicates the qualitative characterization of the state of economic security, makes it difficult to identify threats to economic security, and also does not contribute to the correct setting of priorities in the system of measures to neutralize and prevent threats to the economic security of a country. Thus, these limitations can serve as a basis for further research in the formation of methodological support of the procedure for monitoring threats to the economic security of socioeconomic systems.

\section{REFERENCES}

[1] Name1 N.A., Name2 S. T., Complete Title of the paper, Book/Scientific Journal/Name of the Conference, Country, 1999, pp 45-51;

[2] Name1 N.A., Name2 S. T., Complete Title of the paper, Book/Scientific Journal/Name of the Conference, Country, vol. 3, pp 185-193, 2000.

[3] Name1 N.A., Name2 S. T., Complete Title of the paper, Book/Scientific Journal/Name of the Conference, Country, vol. 1/issue 6, pp 9-10, 2005.

[1] Konstantinov A.V., Kolesnichenko E.A., Yakunina I.N., Motin I.D., Criteria and methods for monitoring threats to economic security in economic sectors in the context of transformation of external determinants, Forestry Engineering Journal, Russia, issue 4, pp. 240-249, 2016.

[2] A.B. Vissarionov, ]Gumerov R.R., On the use of the limit (threshold) values of the economic security indicators of the Russian Federation, Management science, Russia, issue 3, pp. 12-20, 2017.

[3] Vyakina I.V. Security of the economic development of the Russian Federation in the face of growing geopolitical threats, National Interests: Priorities and Security, Russia, issue 5, pp. 178-191, 2016.

[4] Gordienko D.V., Assessment of the level of economic security of China and the USA in the period of the world financial and economic crisis, China in the world and regional policy. history and modernity, 2012, pp. 242-279;

[5] Mityakov E. S., Kornilov D. A., To the question on selecting weights when finding integral indicators of economic dynamics, economics, innovation and management, Russia, issue 2, pp. 112, 2015.

[6] Karpov V.V., Korableva A.A., Theory and practice of the assessment of economic security (on the example of the regions of the Siberian federal district), Novosibirsk, pub. institute of economics and industrial engineering, Siberian branch of the Russian academy of sciences, 2017. 146 p.

[7] Senchagov V.K., Economic security of Russian regions, Nizhny Novgorod, 2012, 344 P.

[8] Kolesnichenko E.A., Osmanov Z.D., Economic security of key sectors of the Russian economy: a structural approach to research, forestry engineering journal, Russia, issue 2, pp. 187-202, 2015. 
[9] Doing Business 2018. Reforming to Create Jobs. A World Bank Group Flagship Report. - Washington, The World Bank Group, 2018. - 312 p.

[10] Federal State Statistic Service. Official web-site. - URL: http://www.gks.ru/

[11] The Central Bank of the Russian Federation. Official web-site. http://www.cbr.ru/statistics/

[12] Federal Customs Service of Russia. Statistics of the RF foreign trade. Official web-site. URL: http://customs.ru/

[13] The Decree of the President of the Russian Federation of May 13, 2017 No. 208 «On the Strategy for Economic Security of the Russian Federation for the period until 2030» http://www.consultant.ru/

[14] Manokhina N.V., Popov M.V., Kolyadin N.P., Zhadan I. E., Economic security: Tutorial, Moscow, Pub. INFRA-M, 2014.

[15] Illarionov A., Criteria for economic security, Issues of economics, Russia, issue 10, 1998 (in Russian). 